\begin{tabular}{ll}
\hline \hline MINING AND METALLURGY INSTITUTE BOR & ISSN: 2334-8836 (Štampano izdanje) \\
UDK: 622 & ISSN: 2406-1395 (Online) \\
\hline \hline
\end{tabular}

\author{
Miroslav Ignjatović, Slavica Miletic ${ }^{* *}$
}

\title{
EVALUATION OF THE SUSTAINABLE DEVELOPMENT BENEFITS IN THE SERBIAN MINING COMPANIES
}

\begin{abstract}
Sustainable development is the most current topic of today; it means a moderate development that meets the needs of the present generation, and does not interdict the needs of future generations. An analysis of the sustainable development benefits in the mining companies (Mining and Smelting Basin Bor, RTB) presents a problem that can be solved using the multi-criteria decisionmaking methods (MCDM). The interest in analyzing the benefits of sustainable development in the Mining and Smelter Basin Bor originated from the fact that the benefits influence the growth, development and survival of the company. One approach based on the AHP method is proposed to solve the complex problem in this paper. The usability and effectiveness of the AHP approach has been considered in the empirical application of the proposed method for assessment the sustainable development benefits in the mining companies of Serbia (RTB Bor).
\end{abstract}

Keywords: sustainable development, AHP method, RTB Bor

\section{INTRODUCTION}

A concept of sustainable development in the modern world implies improving the quality of life with respecting a healthy environment, using the social and economic qualities for both present and future generations [1].

Development of RTB Bor in Serbia depends on many investment factors. But, their development and survival depend to some extent on the benefits of sustainable development: sustainable production and consumption, implementation of the integrated management system (ISM), introduction of clean technology, development of social responsibility and environmental protection. Development of the mining companies in Serbia has a major contribution to the solution of social and demographic issues, positive impact on regional development and external trade balance of the country [2]. RTB Bor is one of the leading manufacturers of copper and precious metals (gold and silver) in Serbia.

Ranking of the sustainable development benefits of the mining companies (RTB Bor) was done implementing the multicriterion decision-making (MCDM) method.

The MCDM technique has the benefit to evaluate the different options according to the different criteria that have different units. Their benefit over the traditional methods is that the deciding criteria have to be converted into the same unit. Another benefit is that they can analyze the quantitative and qualitative evaluation criteria.

This paper deals with a multicriterial analysis of ranking the benefits of sustainable development in the mining compa-

\footnotetext{
${ }^{*}$ Chamber of Commerce of Serbia, miroslav.ignjatovic@pks.rs

${ }^{* *}$ Mining and Metallurgy Institute Bor, Zeleni bulevar 35, 19210 Bor,

e-meil: slavica.miletic@irmbor.co.rs
} 
nies or selection the best alternatives from a set by conflicting attributes.

The main idea of implementation the MCDM methods is an efficient assessment the benefits of sustainable development of the mining companies in order to improve the performances, increase profits, survival, faster risk identification, achievement the strategic goals and stakeholders' demands.

In recent years, MCDM methods are rapidly developed towards an effective methodology for solving the conflicting real problems and have a significant interests of researches in the mining for: selection of the degraded areas [3]; evaluation and selection of the personnel $[4,5,6]$; selection of the optimal integrated management system $[7,8]$; selection of the mining tourism strategy [9]; choice of the suppliers [10]; optimal mining [11]; business strategy selection [12], etc. They have found an application for evaluation the sustainable business [13] and selection the most influential indicator of sustainable development in the mining companies [14].

One of the MCDM methods - the AHP (Analytical Hierarchical Process) method is used in this paper. The AHP method has assessed the benefits of sustainable development of RTB Bor with the given criteria.

\section{EXPERIMENTAL PART}

The concept of sustainable development in the world and in our country is accepted as a condition of survival and development the mining companies. Sustainable development of the mining companies should enable a continuous sustainable long-term economic growth that will be based on the moderate use of natural resources in accordance with the environmental principles and respect for the environment. The benefits of sustainable development for the mining companies are examples of implementation the sustainable development and business.

The objective of this paper is to evaluate the benefits of sustainable development the mining companies in Serbia for the purpose of creating a sustainable business model, providing opportunities for rapid recognition of opportunities, chances, strengths and weaknesses, better mission and vision, better positioning, gaining competition, winning the new products and markets.

The advantages of sustainable development are: sustainable production and consumption, implementation of an integrated management system (ISM), introduction of the clean technology, development of the social responsibility and environmental protection.

Alternative A1: Sustainable production and consumption: designed, real set and operationally managed production and consumption of the mining companies is one of the alternative benefits of sustainable development. Alternative (A1) creates the sustainable models of the mining companies with which the desired results are achieved with the start of exploration of mineral resources.

Alternative A2: Implementation of the ISM. As in the world, and with increasing importance, it has an integrated management system. It is defined as a comprehensive management tool that connects all elements of the business system into a single management system. The optimal model of the integrated management system is a processive [7, 8], supported by the new standard ISO 9001:2015, an international standard that includes the ISO-International Organization for Standardization. Alternative (A2) creates the sustainable business models for the mining companies that are willing to give answers to all stakeholders.

Alternative A3: Introduction of the clean technology as a priority for sustainable development is crucial for development and creation the sustainable business of the mining companies and healthier environment. Problems of pollution as a result of out-of-date technologies, worn out equipment, inadequate use of the secondary raw materials, inefficient use of the natural resources, decision-making without the ade 
quate models, lack of the waste management perceptions and incentives for introduction of the clean production.

Alternative A4: Development of the social responsibility improves a reputation and creates a confidence for the community, employees, users, and all stakeholders. The concept of socially responsible business contributes to a better society and healthy environment. The responsible business of the mining companies is an investment rather than a loss.

Alternative A5: The environmental protection, its requirements are defined with the ISO 14001 standard. Implementation of the ISO 14001 as a benefit of the sustainable development makes the model of mining companies that reduce the environmental pollution, ecological disaster risks, control emissions, execute certain controls related to the production, reduce the operating costs and increase the ability to generate the sustainable production and consumption, which is a condition for getting a successful sustainable business model.

Criteria: Criteria are measures that evaluate the alternatives for evaluating the benefits of sustainable development in RTB Bor, defined by the decision-making team.

Criterion (C1): Informing the employees and their participation in decision making as an important criterion for evaluation the benefit of sustainable development for the mining companies. A certain milestone in the way of information and their participation in a decision-making has been made by the companies in developed countries. Deming gave a major contribution to the employees: it is necessary to introduce a permanent training, improvement and transformation of the employees.

Criterion (C2): Competitiveness: The international competitiveness of a state is the ability to maintain and increase the share of national economy in the market by opening the international standards of the efficiency, sustainable use of the natural resources and product quality [15].

Criterion (C3): Reducing costs; many mining companies have met with demands of the foreign companies, so they are forced to provide the appropriate ISO standards to reduce the costs. The criterion of cost reduction is important for the mining companies in order to increase the production and thereby to increase the profits.

Criterion (C4): Introduction of the new technologies; a trend for drastic increase in the investment in the mining companies in Serbia (construction of the New Smelter in the Mining and Smelting Basin Bor) has been recently seen. This criterion increases the production and sales leading to a greater competitiveness and cooperation with the global companies.

Criterion (C5): Simpler procedures, as a criterion for evaluating the benefits of sustainable development of the mining companies is based on introduction the concept of business quality improvement on the PDCA cycle (Plan, Do, Chek, ACT) which includes: plan, perform, check and control

Criterion (C6): The quality control of the process by Deming is: to design a product, to test the product on the production line or laboratories, to sell the product and test it, to find out what they think about it and those who bought it and who did not. The mining companies in modern business are forced to focus on the quality processes to be sustainable and competitive.

Criterion (C4): The introduction of new technologies has recently seen a trend for a drastic increase in investment in mining companies in Serbia (the production of the New Smeltery in the Mining Smelter Basin Bor). This criterion increases production and sales leading to greater competitiveness and cooperation with global companies. 


\section{EVALUATION OF THE \\ SUSTAINABLE DEVELOPMENT BENEFITS BY THE AHP METHOD}

The problems of evaluation the sustainable development benefits of the mining companies can be overcome using an analytical hierarchy (AHP) which Thomas L. Saaty (1970) introduced into the multicriteria decision-making [16]. This compensatory decision methodology can be applied in various areas of planning, management and solving the real problems.

The AHP includes [17]:

a) Structuring the problem of a hierarchical decision; b) Matrix obtained on the basis of comparative comparison the crite ria and alternatives;

c) The consistency test must be less than 0.1 ;

d) Comparison synthesis in order to obtain an optimal alternative,

e) The evaluation of criteria is done between each other and ranking of the individual alternatives using the Criterion Decision Plus software.

The weight coefficients of the criteria are determined using the scale of comparison the Sati's procedure (Table 1).

Table 1 Scale of comparison the decision elements

\begin{tabular}{lc}
\multicolumn{2}{c}{ Dominances } \\
\hline Description & Rating \\
\hline Equal & 1 \\
\hline Poor domination & 3 \\
\hline Strong domination & 5 \\
\hline Very strong domination & 7 \\
\hline Absolute domination & 9 \\
\hline
\end{tabular}

$2,4,6,8$ are the subtotals

Table 2 Matrix of comparison for criteria

\begin{tabular}{|c|c|c|c|c|c|c|}
\hline Criteria & $\mathbf{C}_{\mathbf{1}}$ & $\mathbf{C}_{\mathbf{2}}$ & $\mathbf{C}_{\mathbf{3}}$ & $\mathbf{C}_{\mathbf{4}}$ & $\mathbf{C}_{\mathbf{5}}$ & $\mathbf{C}_{\mathbf{6}}$ \\
\hline $\mathbf{C}_{\mathbf{1}}$ & 1 & $1 / 5$ & $1 / 3$ & $1 / 3$ & $1 / 2$ & $1 / 3$ \\
\hline $\mathbf{C}_{\mathbf{2}}$ & & 1 & 1 & 3 & 3 & 3 \\
\hline $\mathbf{C}_{\mathbf{3}}$ & & & 1 & 1 & $1 / 2$ & 1 \\
\hline $\mathbf{C}_{\mathbf{4}}$ & & & & 1 & 2 & $1 / 3$ \\
\hline $\mathbf{C}_{\mathbf{5}}$ & & & & & 1 & $1 / 2$ \\
\hline $\mathbf{C}_{\mathbf{6}}$ & & & & & 1 \\
\hline
\end{tabular}

The obtained results are shown in hierarchy of the AHP method.

Table 3. Figure 1 shows the decision

Table 3 Results obtained by the AHP calculations

\begin{tabular}{lllllll} 
Criterion & $\mathbf{C}_{\mathbf{1}}$ & $\mathbf{C}_{\mathbf{2}}$ & $\mathbf{C}_{\mathbf{3}}$ & $\mathbf{C}_{\mathbf{4}}$ & $\mathbf{C}_{\mathbf{5}}$ & $\mathbf{C}_{\mathbf{6}}$ \\
\hline Weight coefficients of criterion & 0.053 & 0.327 & 0.160 & 0.136 & 0.127 & 0.197 \\
\hline Consistency coefficient & 0.084 & & & & &
\end{tabular}




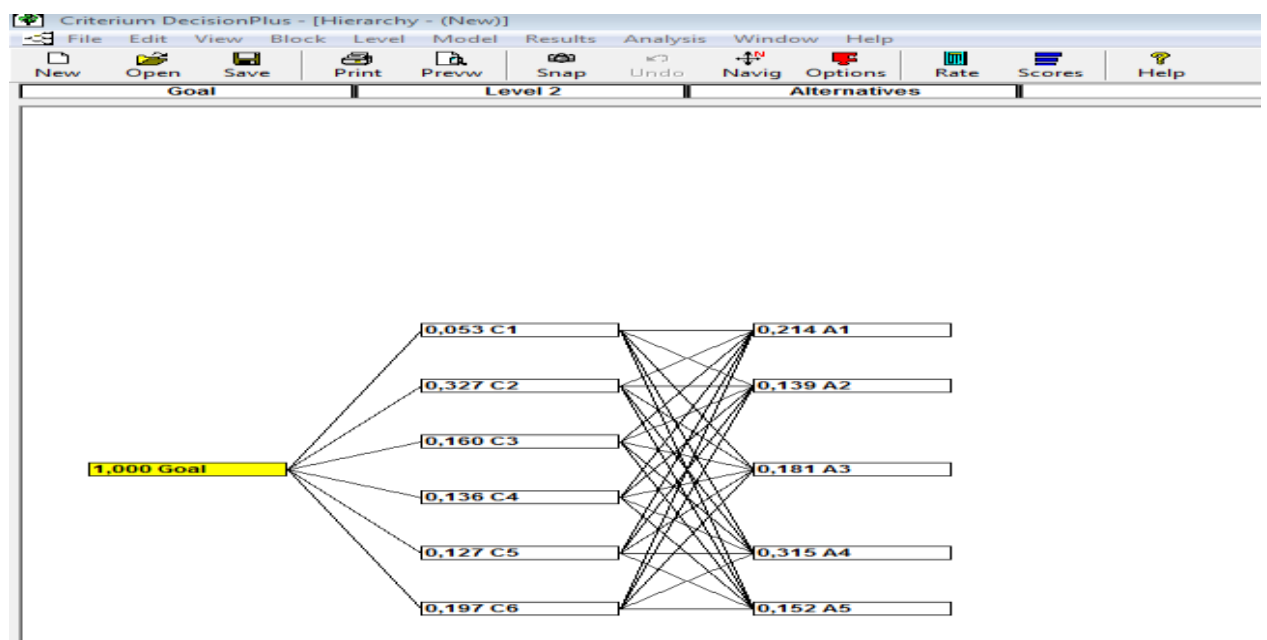

Figure 1 Hierarchy of decision-making

The next step is to evaluate the alterna- the benefits of sustainable development in tives, individually with each $\mathrm{C}_{1}, \mathrm{C}_{2}, \mathrm{C}_{3}, \mathrm{C}_{4}, \quad$ RTB Bor. The choice of criteria is very im$\mathrm{C}_{5}$ and $\mathrm{C}_{6}$. criteria. Alternatives are given as portant for solving the real problems.

Table 4 Comparison of alternatives in relation to the criterion $C_{1}$

\begin{tabular}{cccccc} 
Alternatives & $\mathbf{A}_{\mathbf{1}}$ & $\mathbf{A}_{\mathbf{2}}$ & $\mathbf{A}_{\mathbf{3}}$ & $\mathbf{A}_{\mathbf{4}}$ & $\mathbf{A}_{\mathbf{5}}$ \\
\hline $\mathrm{A}_{1}$ & 1 & 2 & 3 & $1 / 2$ & 1 \\
\hline $\mathrm{A}_{2}$ & 1 & 1 & $1 / 2$ & 3 \\
\hline $\mathrm{A}_{3}$ & & 1 & $1 / 5$ & $1 / 2$ \\
\hline $\mathrm{A}_{4}$ & & & 1 & 3 \\
\hline $\mathrm{A}_{5}$ & & & &
\end{tabular}

Consistency coefficient 0.084

Table 5 Comparison of alternatives in relation to the criterion ${ }_{C 2}$

\begin{tabular}{cccccc} 
Alternatives & $\mathbf{A}_{\mathbf{1}}$ & $\mathbf{A}_{\mathbf{2}}$ & $\mathbf{A}_{\mathbf{3}}$ & $\mathbf{A}_{\mathbf{4}}$ & $\mathbf{A}_{\mathbf{5}}$ \\
\hline $\mathrm{A}_{1}$ & 1 & 1 & 1 & 2 & 1 \\
\hline $\mathrm{A}_{2}$ & 1 & $1 / 3$ & $1 / 2$ & $1 / 2$ \\
\hline $\mathrm{A}_{3}$ & & 1 & $1 / 2$ & 2 \\
\hline $\mathrm{A}_{4}$ & & & 1 & 2 \\
\hline $\mathrm{A}_{5}$ & & & & 1
\end{tabular}

Consistency coefficient 0.095 
Table 6 Comparison of alternatives in relation to the criterion $C_{3}$

\begin{tabular}{cccccc} 
Alternatives & $\mathbf{A}_{\mathbf{1}}$ & $\mathbf{A}_{\mathbf{2}}$ & $\mathbf{A}_{\mathbf{3}}$ & $\mathbf{A}_{\mathbf{4}}$ & $\mathbf{A}_{\mathbf{5}}$ \\
\hline $\mathrm{A}_{1}$ & 1 & 1 & 3 & $1 / 2$ & 2 \\
\hline $\mathrm{A}_{2}$ & 1 & 2 & $1 / 3$ & 1 \\
\hline $\mathrm{A}_{3}$ & & 1 & $1 / 5$ & 1 \\
\hline $\mathrm{A}_{4}$ & & & 1 & 5 \\
\hline $\mathrm{A}_{5}$ & & & & 1 \\
\hline
\end{tabular}

Consistency coefficient 0.017

Table 7 Comparison of alternatives in relation to the criterion $C_{4}$

\begin{tabular}{cccccc} 
Alternatives & $\mathbf{A}_{\mathbf{1}}$ & $\mathbf{A}_{\mathbf{2}}$ & $\mathbf{A}_{\mathbf{3}}$ & $\mathbf{A}_{\mathbf{4}}$ & $\mathbf{A}_{\mathbf{5}}$ \\
\hline $\mathrm{A}_{1}$ & 1 & 2 & 3 & $1 / 2$ & 1 \\
\hline $\mathrm{A}_{2}$ & 1 & 3 & $1 / 3$ & 2 \\
\hline $\mathrm{A}_{3}$ & & 1 & $1 / 5$ & $1 / 2$ \\
\hline $\mathrm{A}_{4}$ & & & 1 & 1 \\
\hline $\mathrm{A}_{5}$ & & & & 1
\end{tabular}

Consistency coefficient 0.072

Table 8 Comparison of alternatives in relation to the criterion $C_{5}$

\begin{tabular}{ccccccc} 
Alternatives & $\mathbf{A}_{\mathbf{1}}$ & $\mathbf{A}_{\mathbf{2}}$ & \multicolumn{1}{c}{$\mathbf{A}_{\mathbf{3}}$} & $\mathbf{A}_{\mathbf{4}}$ & \multicolumn{2}{c}{$\mathbf{A}_{\mathbf{5}}$} \\
\hline $\mathrm{A}_{1}$ & 1 & 2 & $1 / 3$ & $1 / 2$ & 1 \\
\hline $\mathrm{A}_{2}$ & & 1 & $1 / 3$ & $1 / 2$ & $1 / 3$ \\
\hline $\mathrm{A}_{3}$ & & & 1 & 5 & 1 \\
\hline $\mathrm{A}_{4}$ & & & 1 & 1 \\
\hline $\mathrm{A}_{5}$ & & & & & \\
\hline
\end{tabular}

Consistency coefficient 0.079

Table 9 Comparison of alternatives in relation to the criterion C6

\begin{tabular}{cccccc} 
Alternatives & $\mathbf{A}_{\mathbf{1}}$ & $\mathbf{A}_{\mathbf{2}}$ & $\mathbf{A}_{\mathbf{3}}$ & $\mathbf{A}_{\mathbf{4}}$ & $\mathbf{A}_{\mathbf{5}}$ \\
\hline $\mathrm{A}_{1}$ & 1 & 2 & 3 & $1 / 2$ & 1 \\
\hline $\mathrm{A}_{2}$ & 1 & 1 & $1 / 2$ & 2 \\
\hline $\mathrm{A}_{3}$ & & 1 & $1 / 3$ & 2 \\
\hline $\mathrm{A}_{4}$ & & & 1 & 3 \\
\hline $\mathrm{A}_{5}$ & & & & 1 \\
\hline
\end{tabular}

Consistency coefficient 0.067 
The AHP analysis of evaluation the sustainable business benefits in the mining companies shows that the highest benefit has the alternative $\left(\mathrm{A}_{4}\right)$ - development the social responsibility; the second place is the alternative (A1) - sustainable production and consumption; the third place is thealternative $\left(A_{3}\right)$ - introduction of the clean tech nology; the fourth place is the alternative $\left(\mathrm{A}_{5}\right)$ - environmental protection and the fifth place is the alternative $\left(\mathrm{A}_{2}\right)$ - implementation of the integrated management system (Table 10). All alternatives are the benefits of importance for implementation the sustainable development in the mining companies.

Table 10 The final ranking of benefits

\begin{tabular}{|c|c|c|}
\hline Order No. & Benefits & Result \\
\hline 1 & $\mathrm{~A}_{4}$ & 0.315 \\
\hline 2 & $\mathrm{~A}_{1}$ & 0.214 \\
\hline 3 & $\mathrm{~A}_{3}$ & 0.181 \\
\hline 4 & $\mathrm{~A}_{5}$ & 0.152 \\
\hline 5 & $\mathrm{~A}_{2}$ & 0.139 \\
\hline
\end{tabular}

\section{ANALYSIS OF THE RESULTS}

Using the AHP method, the most influential criterion was obtained as well as the certain alternative that has the highest benefit for the sustainable development of RTB Bor.

The results obtained by the AHP calculations (Table 3 ) show that the criterion $\mathrm{C}_{2}$ competitiveness has the highest impact on the obtained result because its weight coefficient is 0.357 ; the second position occupies the criterion $\mathrm{C}_{6}$ - quality control of the process with a weight coefficient of 0.197 ; in third place is the criterion $\mathrm{C}_{3}$ - reduction of costs with a weight coefficient of 0.160 ; the fourth is the criterion $\mathrm{C}_{4}$ - introduction of the new technologies with a weight coefficient of 0.136 ; the fifth place is the criterion $\mathrm{C}_{5}$ - simpler procedures with a weight coefficient of 0.127 and the sixth place is the criterion $\mathrm{C}_{1}$ - information of the employees and their participation in a decisionmaking with a weight coefficient of 0.053 .

Evaluation the sustainable development benefits in the mining companies by the AHP calculation results in a fact that has the highest benefit has the alternative $\mathrm{A}_{4}$ - development of the social responsibility, which has a maximum value of 0.315 ; the second place is the alternative $\mathrm{A}_{1}$ sustainable production and consumption with a value of 0.214 ; the third place is the alternative $\mathrm{A}_{3 \mathrm{c}^{-}}$introduction of the clean technology with a value of 0.181 ; the fourth place is the alternative $A_{5}$ - environmental protection with a value of 0.152 ; the fifth place is the alternative $A_{2}$ - implementation the integrated management system with a value of 0.139 (Table 10). 


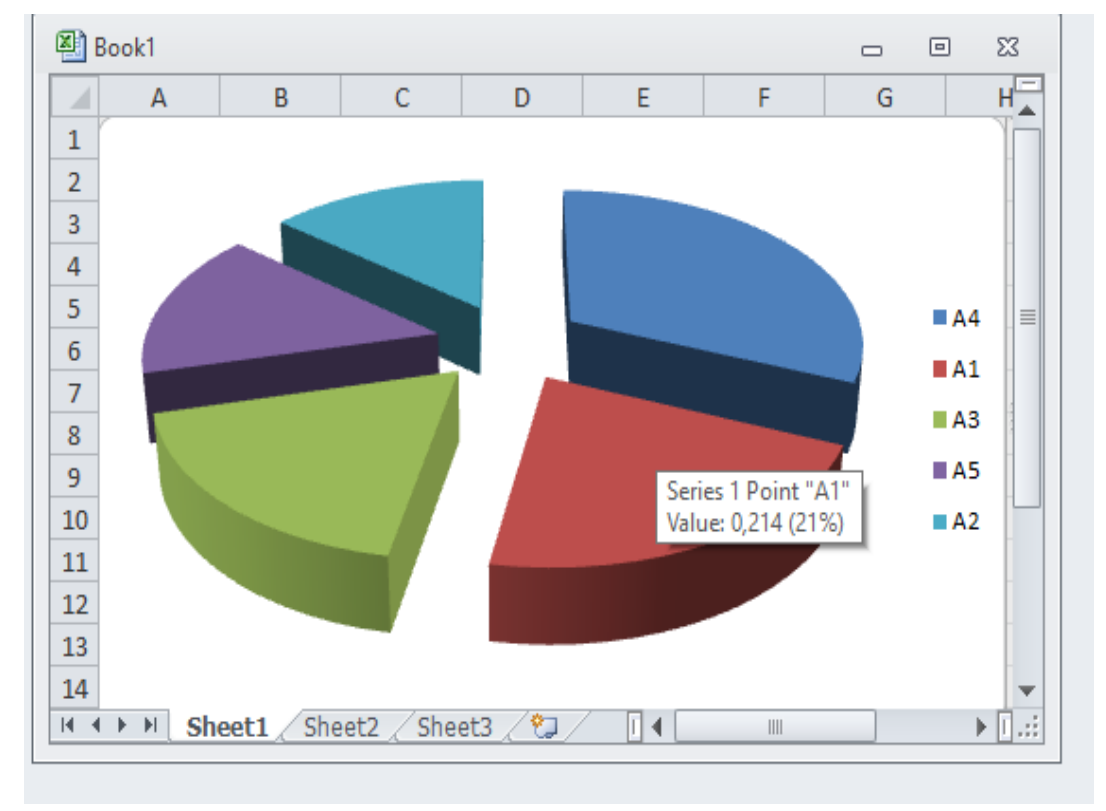

Figure 2 Graph of evaluation the sustainable development benefits in the mining

Figure 2 shows a graph of evaluating the benefits of the mining company (RTB Bor) in implementation the sustainable development. Calculation resulted in a fact that all benefits are almost equal. The responsible business as the best benefit of sustainable development means: investments for introducing the new and clean technologies for sustainable production and consumption, development the awareness of environmental protection and implementation the integrated management system (ISM). The responsible business improves the image of mining companies, creates confidence and thus increases the competition.

Alternative $\mathrm{A}_{4}$ - development of the social responsibility does not create a loss but a prosperity (satisfaction) for all interested parties.

\section{CONCLUSION}

The applied MCDM methodology for evaluating the benefits of sustainable development creates a perception for implement- tation the sustainable develop-ment and creation a sustainable business model. An assessment of the sustainable development benefits gives stakeholders the opportunity to better understand the chances, opportunities, strengths and weaknesses of RTB Bor to the aim of sustainability, competitiveness and profitability.

The AHP method was used to evaluate the benefits of sustainable development. The assessment of the following alternatives was made: sustainable production and consumption $\left(A_{1}\right)$, implementation of integrated management system (ISM) $\left(\mathrm{A}_{2}\right)$, introduction of the clean technology $\left(A_{3}\right)$, development of the social responsibility $\left(\mathrm{A}_{4}\right)$ and environmental protection $\left(\mathrm{A}_{5}\right)$. CAlculation has provided that the alterna-tive $\mathrm{A}_{4}$ - development of the social responsibility has the highest value showing that it is the best advantage.

The following criteria were used to evaluate the benefits of sustainable development: information about employees and their participation in a decision-making 
$\left(\mathrm{C}_{1}\right)$, competitiveness $\left(\mathrm{C}_{2}\right)$, cost reduction $\left(\mathrm{C}_{3}\right)$, introduction of the new technologies $\left(\mathrm{C}_{4}\right)$, simpler procedures $\left(\mathrm{C}_{5}\right)$, quality process control $\left(\mathrm{C}_{6}\right)$. The criterion $\mathrm{C}_{2}$ - competitiveness has the greatest impact on evaluating the benefits of sustainable development in the mining companies.

Based on all of these, the future research should be directed towards the implementtation of sustainable development in the mining companies.

A contribution of this paper is the perception for implementation the sustainable development in order to the company survival and meeting the requirements of stakeholders.

A contribution of science is focused on expanding the theoretical and practical knowledge on implementation the sustainnable development in the mining companies.

\section{REFERENCES}

[1] Ortiz O., Castells F., Sonnemann G., Sustainability in the Construction Industry: A Review of Recent Developments Based on LCA. J. Constr. Build. Mater.23 (1), (2009), 28-39.

[2] Radosavljević M., Effect of Use the International Standards for the Management Systems in the Mining of Serbia, Doctoral Dissertation, University in Belgrade, Faculty of Organizational Sciences (2016) (in Serbian)

[3] Bogdanović D., Obradović Lj., Miletić S., Selection the Optimum Method of Rehabilitation the Degraded Areas around the Bor River Downstream from the Flotation Tailing Dump Bor. Journal Mining and Metallurgy Engineering Bor, 4, (2014), pp. 137-156.

[4] Bogdanovic D.; Miletic S., Personnel Evaluation and Selection by the Multicriterion Decision-Making Method. Economic Computation and Economic Cybernetics Studies and Research, 48(3), (2014), 179-196.
[5] Karabašević D., Stanujkić D., Urošević S., Maksimović M., Selection of Candidates in the Mining Industry Based on the Application of the Swara and the Multimoora Methods. Acta Montanistica Slovaca, 20 (2), (2015), 116-124.

[6] Stanujkic D., Karabašević D. \& Zavadskas E.K., Anew Approach For Selecting the Alternatives Based on the Adapted Weighted Sum and the Swara Methods: A Case of Personnel Selection, Economic Computation and Economic Cybernetics Studies and Research, 3(51), (2017). 39-56.

[7] Miletić S., Bogdanović D., Paunković J., Selection the Optimal Model of Integrated Sustainable Management System in the Mining Companies. Journal Mining and Metallurgy Engineering Bor, 2, (2015), 181-204.

[8] Miletić S., Bogdanović D., Milanović D., Advantages of Implementation the Process Model for Sustainable Business Operations of Mining Companies. Journal Mining and Metallurgy Engineering Bor, 3, (2016), 71-82.

[9] Maksimović M., Urošević S., Stanujkić D., Karabašević D., Selection a Development Strategy of Mining Tourism Based on the Grey Relational Analysis. Mining and Metallurgy Engineering Bor, 1, (2016), 115-124.

[10] Keshavarz G.M., Zavadskas E.K., Amiri M., Turskis Z., Extended EDAS Method for Fuzzy Multi-criteria Decision-making: An Application to Supplier Selection. International Journal of Computers, Communications \& Contro, 11(3), (2016), 358-371.

[11] Stevanović D., Lekić M., Kržanović D., Ristović I., Application of MCDA in Selection of Different Mining Methods and Solutions, Advances in 
Science and Technology Research Journal, 12(1), 2018, 171-180

[12] Janovac T., Karabašević D., Maksimović M., Radanov P., Selection of the Motivation Strategy for Employees in the Mining Industry Using the Gra Method, Journal Mining and Metallurgy Engineering Bor, (2018), $157-164$

[13] Miletić S., Bogdanović D., Paunković Dž., Mihajlović D., Usage of rhe Multicriterion Decision-Making to the Aim of Evaluation the Suistanable Business of the Mining Companies, Reciklaža i održivi razvoj, 9, (2016), 15-20 (in Serbian)

[14] Miletić S., Bogdanović D., Paunković Dž., Evaluation the Sustainability for Decision-Making in the Mining
Companies, Megatrend revija, (2016), 83-96 (in Serbian)

[15] Velloso J.P.R., International Competitiveness and Creation of an Enabling Environment, Haque, I.ul International Competitiveness: Interaction of Public and Private Sectors, Washington, D.C.: World Bank, (1991).

[16] Kousalya P., Reddy M.G., Supraja S., Prasad V.S., Analytical Hierarchy Process Approach - An Application of Engineering Education. Math Aeterna. 2, (2012). 861-78.

[17] Yang, I.T., Wang, W.C, Yang, T.I., Automatic Repair of Inconsistent Pairwise Weighting Matrices in Analytic Hierarchy Process. Autom Constr, 22, (2012), 290-297. 